\title{
Impact of dam-building on marine life
}

\author{
T. J. Pandian \\ School of Biological Sciences, Madurai Kamaraj University; Madurai, India
}

\begin{abstract}
Dam-building across naturally flowing rivers tends to decrease discharge of surplus water into the sea, reduce nutrient concentration in estuaries and coastal waters, and diminish plankton blooms as well as fish landings. Depletion of nutrients and organic matter along with reduced mud and silt deposition affect benthic life on the continental shelf. Reduced mud and silt deposition leads to coastal retreat. Dams, especially those constructed for hydro-electric purposes, hinder migration of fishes and decapods. Discharge from dams can create barriers at high or low flows, cause delays, disrupt normal behavioural routine and change the travel speed of migratory animals. Where all spawners of a given population are frequently kept away from the breeding site, the population faces extinction.
\end{abstract}

\section{INTRODUCTION}

The extent to which marine life is threatened by dam-building is under dispute. The completion of some of the large African dams during the 1960 s had such a marked effect that a number of publications during "the environmental decade" gave the public the impression that river development anywhere in the world would necessarily be uncompromisingly incompatible with environmental well-being (Farvar \& Milton, 1972). On the other hand, publications by Shkharev (1979) and others elaborate the advantages gained through the construction of the high dam at Aswan. Scientists in far-east countries have emphasised that the environmental effects of river development are not always harmful.

During the last two centuries, the increasing demand for food has been the major impetus for expansion of irrigation. Today there are about 200 million ha of land under irrigation (Brown \& Finsterbusch, 1972). The benefits of dams in terms of agricultural expansion, hydro-electric power generation, industrialisation, navigation, development of game and sports and rehabilitation of populations are apparent. However, dambuilding across naturally flowing rivers poses a possible threat to normal activities of marine life. This threat is discussed under the headings: world climatic changes plankton blooms and fish landings; coastal retreat; obstruction of spawning migrants; the Mekong basin.

\section{WORLD CLIMATIC CHANGES}

Evaporation, precipitation, detention and transportation of water maintain a stable balance on the earth. The oceans receive $112 \mathrm{~cm}$ of precipitation a year but lose $135 \mathrm{~cm}$ in evaporation - a net loss of $23 \mathrm{~cm}$ annually. Precipitation on land in excess of evapora- 
tion is eventually carried to the sea by rivers. Rivers are prime movers of water over the globe; by returning water to the sea they tend to balance the evaporation deficit of the oceans (Budyko, 1963).

I shall briefly discuss here two examples of climatic changes that are predicted to occur when some of the contemplated major dams are constructed. Dam-building across naturally flowing rivers tends to reduce or prevent discharge of surplus water into the sea. The construction of the so-called century storage at the high dam of Aswan impounds 160 billion $\mathrm{m}^{3}$ of water and thus prevents at least a major part of this water ever reaching the Mediterranean. The imposed water deficit may be marginal to the large open oceans but it is critical for land-locked aquatic bodies like the Aral Sea, Caspian Sea and Black Sea. For instance, the level of the Aral Sea dropped nearly $1.75 \mathrm{~m}$ between 1961 and 1967. Likewise, impoundment of water at the great Volga Project is one of the reasons for the shrinking of the Caspian Sea, exposing large banks $(40 \mathrm{~km}$ width) in the south (Teclaff \& Teclaff, 1972).

A possible solution to these problems is the large-scale transbasin diversion of the three major Siberian rivers now flowing into the Arctic Sea. By depriving the Arctic of freshwater, the climatic belt of the world would be shifted northward and possibly even cause greater deserts in the United States (Mauthner, 1970). Besides, the spring breakup of ice in the lower reaches of these northwardly flowing Siberian and Canadian rivers is hastened by the hydrostatic pressure generated by flood waters from the more southern part of the rivers flowing beneath it. Consequently, a reduction in the maximum flow of the river would probably delay the beginning of spring (Vendrov, 1965; Gill, 1971).

\section{PLANKTON BLOOMS AND FISH LANDINGS}

Hydrographically, the Nile is one of the best-known rivers in the world (Hurst, 1957). This river is chosen for the purpose of explaining the negative effects of dambuilding on fish landings and coastal retreat. The first dam across the Nile was completed in 1902; its storage capacity was doubled by the first heightening in 1912, and was multiplied fivefold in 1934. Subsequently, Sennar Dam in the Blue Nile (1925), Jebel Aulia Dam in the White Nile (1937), Khashm el-Girba Dam in the Albara (1962), and Rosieres Dam in the Blue Nile (1964) were constructed. In addition, a number of barrages - namely Mohammed Ali in 1900, Asiut in 1902, Isna in 1908 and Nag-Hamadi in 1930 were constructed; these barrages were also enlarged.

The flood season of the Nile usually commences in mid-August, reaches its climax in mid-September, gradually fades away during November and ceases in December. With the construction of the old Aswan Dam in 1902, the discharge from the Nile into the Mediterranean Sea was reduced to 1,820 million $\mathrm{m}^{3}$ water $\mathrm{d}^{-1}$ (Willcocks, 1904, cited in Farvar \& Milton, 1972). With construction of a number of dams and barrages between 1902 and 1964, the discharge of the Nile was further reduced to about 640 million $\mathrm{m}^{3} \mathrm{~d}^{-1}$ and even the reduced discharge has completely stopped since 1965.

During the flood season, the discharged Nile water is known to carry $4 \mathrm{~kg}$ silt and mud $\mathrm{m}^{-3}$ as well as $6.4 \mu \mathrm{g}$ phosphate and $340 \mu \mathrm{g}$ silicate ${ }^{-1}$ (Emery \& George, 1963). The fertility of the Mediterranean Sea is quite low $\left(0.1 \mu \mathrm{g} \mathrm{PO}_{4} 1^{-1}\right.$; George, 1972). Therefore, the statement of Herodotus that "Egypt is the gift of Nile" holds equally true for the 
Mediterranean Sea. Soon after the Nile entered the sea, massive outbursts of phytoplankton developed along the delta coast until 1965; phytoplankton counts increased from about 0.5 million cells $\mathrm{l}^{-1}$ (Bernard, 1958a, b) to 9-10 million cells $1^{-1}$ (Aleem, 1972). This was followed by zooplankton blooms.

Between the two outlets of the Nile, clupeoids (mainly Sardinella aurita and S. eba) constitute the major fishery. The sardines concentrate in coastal waters from September to December. During this period between 10,000 and 20,000 t of Sardinella are caught by gill nets. The fact that the Sardinella catches dropped to only $554 t$ in 1966, when Nile water was not let into the sea, reveals that Sardinella concentrations in coastal waters were closely linked to plankton blooms, which flourished as a result of huge amounts of inorganic nutrients discharged with Nile water (Aleem, 1972).

Carangids, mullids and the penaied shrimps constitute the major demersal fisheries of the Nile delta. High concentrations of detritus and dissolved organic matter, resulting from decomposition of surface phytoplankton blooms during the Nile flood, also contribute to the food of demersal organisms. As a consequence of the cessation of influxes of the Nile water into the sea, this "food source" is not now replenished annually. During the last few years, the demersal fishery declined to a significant level; for instance, the landings of shrimp catches dropped to less than half (Aleem, 1972).

\section{COASTAL RETREAT}

When a dam is constructed, preventing or reducing water flow into the sea, the balance between forces controlling sand deposition along the coast and erosion (coastal currents, waves, wind) is upset, with the result that erosion factors work faster. Erosion was operating at certain points of the Nile delta, even before the construction of the High Dam in 1965. The shore line at the western side of the Rosetta mouth of the Nile has retreated about $30 \mathrm{~m}_{\text {annum }}{ }^{-1}$ since 1898 (Wassing, unpublished). Likewise, the site of Ras el Bar on the western side of the mouth of Damietta distributory has been receding at the rate of $31 \mathrm{~m}^{\text {annum }}{ }^{-1}$ since 1902 .

The construction of the Sennar Dam in the Blue Nile in 1925 in Sudan and the old Aswan Dam in the Nile in 1902 in Egypt interfered with sediment deposition in the sea during the period in which the retreat of the Nile delta was about $30 \mathrm{~m}$ annum $^{-1}$. The Blue Nile carries about 100-130 million $t$ of silt during the flood season (Hammerton, 1972). The river carried up to Wadi Halfa (Sudano-Egyptian border) 110 million $t$ sediments; by the time it reached Cairo, it contained only 58 million $t$ sediments. Sediment is further lost from Cairo to the sea (Ball, 1939). This loss is mostly due to interception of the sediments through irrigation canals and the Aswan reservoir (Kassas, 1972).

In 1904, two years after the old Aswan dam was constructed, Willcocks $(1904$, cited in Farvar \& Milton, 1972) calculated that out of the discharge of $3040 \mathrm{~m}^{3} \mathrm{~s}^{-1}$, which passes the Aswan, $2100 \mathrm{~m}^{3} \mathrm{~s}^{-1}$ reached the sea. Subsequently, a number of dams and barrages were constructed (see previous section). Deposition of sediments until 1902 was enough to compensate for erosion loss and for building the delta shore further northward. With the construction of more and more dams on the Nile and its tributaries, the protective influence of the river flow has gradually and progressively been diminished. It was completely nullified on the completion of Aswan High Dam, as this has brought 
the Nile in Egypt under full control and reduced water discharge and its load of sediment into the sea to almost nil.

Dikes have been constructed in several areas of the North Sea coast. The various biological consequences of these constructions cannot be considered here in detail.

\section{OBSTRUCTION OF SPAWNING MIGRANTS}

Dams, constructed especially for hydro-electric power generation, obstruct spawning migrations of fishes and decapods. A large number of studies on spawning migrants have been made in the USA. From these I have chosen the following examples.

Catadromous migrants. Among the catadromous migrants, eels are the most important in terms of numbers. However, elvers can negotiate obstacles that would be impossible for adult salmon, and there is no evidence that they seek out the stream from which their parents came so that the danger of depletion of eels as a consequence of hydro-electric development does not appear serious (Baxter, 1977).

Anadromous migrants. Between 1927 and 1941, several dams were constructed on the Columbia River in USA. These dams brought about dramatic changes in the characteristics of the river, creating temporary barriers to migratory fishes from the uppermost Grand Coolie Dam over a distance of $1600 \mathrm{~km}$.

Upstream anadromous migrants. Pacific salmon (Oncorhynchus spp.) and trout (Salmo spp.) do not feed on their way to the spawning grounds, and the reserve energy in their body is just little more than sufficient to bring them to their destination (Idler \& Clemens, 1959). Hence, the time lost in additional movement (in a region of slack water above a dam) could minimize the chances of reproduction.

Population counts of adults at successive dams in the Columbia River revealed a cumulative survival of trout and salmon only up to $60 \%$. Consequently, the catch, for instance of Pacific salmon decreased from 22 to 7 million $\mathrm{kg}$ (Trefethen, 1972). Besides, there are races of salmon perpetuated from specific "spawning homes". When dams deprive access to these "spawning homes", a given race is liable to be destroyed (for examples see Hubbs \& Pigg, 1976).

Table 1. Effects of impounding the Snake and Columbia rivers on the rate of migration of juvenile Oncorhynchus tshawytscha (after Trefethen, 1972; modified)

\begin{tabular}{|lccc|}
\hline Section of river & $\begin{array}{c}\text { Distance } \\
(\mathrm{km})\end{array}$ & $\begin{array}{c}\text { Elapsed time (days) } \\
\text { Pre-impoundment }\end{array}$ & 15 \\
\hline Salmon River to Ice Harbor Dam & 370 & 3 & 25 \\
Ice Harbor Dam to McNary Dam & 68 & 5 & 9 \\
McNary Dam to John Day Dam & 122 & May 2 & June 3 \\
Peak of migration John Day Dam & & & \\
\hline
\end{tabular}

Downstream anadromous migrants. Successive impoundments have reduced the flow velocity of the Columbia and affected downstream migration of salmon and trout. Juvenile migrants of Oncorhynchus tshawytscha required almost 3 times longer to cover a total distance of $560 \mathrm{~km}$ interspersed by 3 dams (Table 1; Raymond, 1968, 1970). 
Downstream juvenile migrants in the reservoir may go over the spillway (Geen, 1974) or pass through the turbines and suffer 10 to $20 \%$ mortality (Long \& Marquette, 1972).

\section{THE MEKONG BASIN}

In contrast to these harmful effects of dam construction in Europe, Africa and America, the environmental situation in tropical Asia, especially in the Mekong river system, appears to pose no pollution threat. Pantulu (1975) claims that the Mekong is a relatively "clean" river - carrying a small quantity of alluvium (20-500 ppm) - in comparison to the Nile (1500 ppm), the Ganges (1950 ppm) and the Mississippi (1750 $\mathrm{ppm}$ ), and hence may carry very little inorganic nutrients to the sea. Sediment deposition does not measurably increase soil fertility in the Mekong delta.

Pantulu (1973) further claims that in the Mekong there are only 7 species of carps and catfishes which are commercially important anadromes. Pangasianodon gigas, which spawns above the Pa Mong dam site, would be kept from its breeding site (Bardach, 1972). Among the other migrants, most undertake lateral migrations to the rice fields and other low-lying areas submerged with the onset of floods. A decapod migrant to the estuary is the giant freshwater prawn Macrobrachium rosenbergii. The possibility of inducing spawning in these migrants may solve the problem of spawning-migrant obstruction when a dam is built. This suggestion may be given due consideration even in the case of salmon in view of the fact that it has been possible to induce spawning in carps in lentic environments. It has also been possible to artificially incubate the eggs of $M$. nobilii and hatch them with $98 \%$ success (Pandian \& Balasundaram, 1980). Stray reports on induced spawning through ablation of eye stock are not uncommon (e. $\mathrm{g}$. Wickins, 1976). Anguilla japonica and A. mauritiana are the two catadromes in the lower Mekong basin, but Pantulu (1973) states that they are of little commercial value.

Clearly, no two river systems are alike, especially if they are located in different ecological zones and hence extrapolation of information from one river system to another is not necessarily valid. Through adequate preparatory studies and implementation of effective precautionary measures, it may be possible to alleviate or offset the adverse effects of dam construction, at least in tropical Asia.

The construction of large dams and other water development projects will continue in the foreseeable future. There is now more of an awareness of the need to assess the ecological impact of water development projects than ever before. Many governments require such assessments before construction. Assessment studies should be conducted in advance of planning the physical features of the project (see also Fraser, 1972).

Acknowledgements. A travel grant and financial support offered to me by Prof. O. Kinne (Hamburg) and DAAD (Bad Godesburg) are gratefully acknowledged. Dr. J. Muthukrishnan, Mrs. S. Mumtaz and Miss S. Nageswari helped in the preparation of the manuscript.

\section{LITERATURE CITED}

Aleem, A. A., 1972. Effect of river outflow management on marine life. - Mar. Biol. 15, 200-208. Ball, J., 1939. Contribution to the geography of Egypt. - Spec. Publ. Survey Mines Dep. 
Bardach, J. E., 1972. Some ecological implications of Mekong river development plans. In: The careless technology. Ed. by M. T. Farvar \& J. P. Milton. The Natural History Press, Garden City, 236-256.

Baxter, R. M., 1977. Environmental effects of dams and impoundments. - A. Rev. Ecol. Syst. 8, 255-283.

Bernard, F., 1958a. Le problème biologique de la fertilité marine élémentaire. -Bull. Soc. Hist. nat. Afr. $49,44-73$.

Bernard, F., 1958b. Données récentes sur la fertilité élémentaire en Méditerranée. - Rapp. P. - v. Cons. Réun. perm. int. Explor. Mer. 144, 103-108.

Brown, L. R. \& Finsterbusch, G. W., 1972. Man and his environment: food. Harper \& Row, New York, $208 \mathrm{pp}$

Budyko, M. I., 1963. The heat budget of the earth. Hydrological Publishing House, Leningrad, 474 pp.

Emery, K. O. \& George, C. J., 1963. The shores of Lebanon. - Misc. Pap. Am. Univ. Beirut, 1963, $1-90$.

Farvar, M. T. \& Milton, J. P., 1972. The careless technology. The Natural History Press, Garden City, $1030 \mathrm{pp}$.

Fraser, J. C., 1972. Regulated discharge and the stream environment. In: River ecology and man. Ed. by R. T. Oglesby, C. A. Carlson \& J. A. McCann. Acad. Press, New York, 263-286 pp.

Geen, G. H., 1974. Effects of hydroelectric development in Western Canada on aquatic ecosystems. - J. Fish. Res. Bd Can. 31, 913-927.

George, C. J., 1972. The role of the Aswan highdam in changing the fisheries of the south eastern Mediterranean. In: The careless technology. Ed. by M. T. Farvar \& J. P. Milton. The Natural History Press, Garden City, 159-178.

Gill, D., 1971. Damming the Mackenzie. In: Proceedings of the Peace Athabasca Delta Symposium. Univ. Alberta Press, Edmonton, 204-222.

Hammerton, D., 1972. The Nile river - a case history, In: River ecology and man. Ed. by R. T. Oglesby, C. A. Carlson, \& J. A. McCann. Acad. Press, New York, 171-214.

Hubbs, C. \& Pigg, J., 1976. The effects of impoundments on threatened fishes of Oklahoma. - Ann. Okla. Acad. Sci. 5, 113-117.

Hurst, H. E., 1957. The Nile. Constable, London, $331 \mathrm{pp}$.

Idler, D. R. \& Clemens, W. A., 1959. The energy expenditures of Fraser river sockeye salmon during the spawning migration of Chilko and Stuart Lakes. - Prog. Rep. Int. Pacif. Salmon Fish. Commn $6,1-80$.

Kassas, M., 1972. Impact of river control schemes of the shoreline of the Nile delta. In: The careless technology. Ed. M. T. Farvar \& J. P. Milton. The Natural History Press, Garden City, 179-188.

Long, C. W. \& Marquette, W. M., 1972. Research on fingerling mortality in Kaplan turbines. - Proc. bienn. Hydraulics Conf. Moscow, Idaho 6, 11-36.

Mauthner, G., 1970. How the Soviet Union will change the earth's climate. - Atlas 1970, 47-48.

Pandian, T. J. \& Balasundaram, C., 1980. In vitro culture of Macrobrachium eggs and the possibility of increasing brood number. - Hydrobiol. (In press.)

Pantulu, V. R., 1973. Fishery problems and opportunities in the Mekong. In: Man-made lakes: their problems and environmental effects. Ed. by W. C. Ackermann, G. F. White \& E. B. Worthington. Am. Geophysical Union, Washington, D. C., 672-681.

Pantulu, V. R., 1975. Environmental aspects of river developments in tropical Asia with particular reference to the Mekong Basin. - Proc. Sect. Wld. Congr. Intern. Wat. Res. Ass. 5, 349-360.

Raymond, H. L., 1968. Migration rates of juvenile chinook salmon in relation to flows and impoundments in Columbia and Snake rivers. - Trans. Am. Fish. Soc. 97, 356-359.

Raymond, H. L., 1970. A summary of the 1969 and 1970 outmigration of juvenile chinook salmon and steelhead trout from the Snake river. Nat. Mar. Fish. Serv., Biol. Lab., Seattle, Wash. 14 pp. (Unpubl. Ms.)

Shkharev, G., 1979. Truth and falsehood about the Aswan Dam. APN Publishing House, Moscow, $90 \mathrm{pp}$.

Teclaff, L. A. \& Teclaff, E., 1972. A history of water development and environmental quality. In: Environmental quality and water development. Ed. by C. R. Goldman, J. McEvoy III \& P. J. Richerson. Freeman, San Franscisco, 26-77. 
Trefethen, P., 1972. Man's impact on the Columbia river. In: River ecology and man. Ed. by R. T. Oglesby, C. A. Carlson \& J. A. Mc Cann. Acad. Press, New York, 77-98.

Vendrov, S. L., 1965. A forecast of changes in natural conditions in the northern Ob basin in case of construction of the lower Ob hydro project. - Izv. Acad. nauk SSR. (Geogr.) 5, 37-49.

Wickins, J. F., 1976. Prawn biology and culture. - Oceanogr. mar. Biol. 14, 435-507. 